\title{
EFEKTIVITAS PENERAPAN PERENCANAAN PULANG DENGAN METODE TERSTRUKTUR TERHADAP KESIAPAN KELUARGA DALAM MEMBERIKAN MOBILISASI DINI PADA PASIEN CEREBRO VASKULER ATTACK DI RS. ISLAM SURABAYA
}

\author{
Siti Damawiyah, Nur Ainiyah \\ Universitas Nahdlatul Ulama Surabaya, Jln. Smea no 57 Surabaya \\ damasiti@unusa.ac.id
}

\begin{abstract}
Discharge Planning in Surabaya Islamic Hospital done only when the patient will discharge in the form of discharge instructions. Providing health education to patients and families still incidental, which is given when the patient or his family have any question and it does not well prepared as a health education that suit with the patient's condition.

This study uses quasy Experimental design, Control Group Pre Test - Post Test Design. Sample of this study are the family of stroke patients who were admitted in Surabaya Islamic Hospital with amount 30 respondents (15 respondents as treated group and 15 others as control group). Samples were taken by consecutive sampling technique. Statistically data analysis uses Mann Whitney test with a significance level 5\% (0.05).

Results of this study showed that the readiness of the treated group increased after a given structured discharge planning, from percentage value $0 \%$ to $53,33 \%$. Results of statistically test by Mann Whitney got $\mathrm{p}$ value of readiness before and after giving structured discharge planning $=0.001(\mathrm{p}<0.05)$ means there is influence nursing in the treated group.

Application of structured discharge planning increases readiness of families in caring for stroke patients in Surabaya Islamic Hospital. It is suggested in future studies to expand the study population and the discharge planning followed up until at home.
\end{abstract}

Key words : Discharge Planning, Readiness

\begin{abstract}
ABSTRAK : Perencanaan pulang di RS. Islam Surabaya dilakukan pada saat pasien akan pulang saja yaitu berupa petunjuk pasien pulang. Pemberian health education kepada pasien dan keluarga masih bersifat incidental, diberikan jika ada pertanyaan dari pasien atau keluarganya saja dan belum dikemas dalam format pendidikan kesehatan yang sesuai dengan Penelitian ini bertujuan untuk mengetahui pengaruh penerapan perencanaan pulang dengan metode terstruktur terhadap kesiapan keluarga dalam memberikan mobilisasi dini pada pasien cerebro vaskuler attack di RS. Islam Surabaya. Penelitian ini menggunakan desain Quasy Experimental, Control Group Pre Test-Post Test Design. Populasi dalam penelitian ini adalah semua keluarga penderita CVA yang dirawat di RS. Islam Surabaya pada saat penelitian sebanyak 34 orang. Sampelnya adalah keluarga penderita stroke yang dirawat di RS. Islam Surabaya sebanyak 30 responden (15 responden kelompok perlakuan dan 15 responden kelompok kontrol).Teknik pengambilan sampel dengan consecutive sampling. Analisis data menggunakan uji statistik Mann Whitney dengan tingkat signifikansi 5\% (0,05). Hasil penelitian menunjukkan kesiapan kelompok perlakuan meningkat sesudah diberikan perencanaan pulang dengan metode terstruktur yaitu dari nilai persentase siap $0 \%$ menjadi 53,33\%. Hasil uji statistik dengan Mann Whitney didapatkan nilai $\mathrm{p}=0,001(\mathrm{p}<0,05)$ berarti terdapat pengaruh sebelum dan sesudah diberikan penerapan perencanaan pulang dengan metode terstruktur terhadap kesiapan keluarga dalam memberikan mobilisasi dini pada pasien cerebro vaskuler attack pada kelompok perlakuan.
\end{abstract}


Penerapan perencanaan pulang dengan metode terstruktur meningkatkan kesiapan keluarga dalam memberikan mobilisasi dini pada pasien cerebro vaskuler attack di RS. Islam Surabaya. Diharapkan pada penelitian selanjutnya untuk melakukan perluasan populasi penelitian dan perencanaan pulang diikuti sampai dirumah.

Kata kunci : Perencanaan pulang, Kesiapan keluarga, Mobilisasi dini

\section{LATAR BELAKANG}

Cerebro vascular attack atau disebut stroke merupakan suatu kondisi yang terjadi ketika pasokan darah ke otak terputus akibat penyumbatan atau pecahnya pembuluh darah, sehingga terjadi kematian selsel pada sebagian area di otak (Lanny, 2013). Manifestasi klinis dari stroke diantaranya adalah kehilangan motorik, kehilangan komunikasi, gangguan persepsi yaitu ketidakmampuan menginterpretasikan sensasi, gangguan fungsi kognitif dan efek psikologis dimana pasien menunjukkan gejala lapang perhatian terbatas, kesulitan dalam pemahaman, pelupa dan kurang motivasi sehingga pasien sering mengalami frustasi dalam perawatan penyembuhan. Stroke adalah penyebab utama hilangnya hari kerja dan kualitas hidup yang buruk, kecacatan akibat stroke tidak hanya berdampak bagi penyandangnya, namun juga bagi anggota keluarganya. Hal inilah yang menimbulkan stigma menakutkan dari penyakit stroke dikalangan masyarakat, belum lagi perubahan kondisi psikologis pasien pasca stroke yang biasanya merasa rendah diri, emosi yang tidak terkontrol, dan selalu ingin diperhatikan (Smeltzer\&Bare, 2008).

Stroke saat ini merupakan penyebab kematian kedua terbanyak di seluruh dunia setelah penyakit jantung dan menempati urutan pertama dalam hal penyebab kecacatan fisik. Menurut WHO, Indonesia telah menempati peringkat ke-97 dunia untuk jumlah penderita stroke terbanyak dengan jumlah angka kematian mencapai 138.268 orang atau 9,70\% dari total kematian yang terjadi pada tahun 2011(Febrie, 2013). Hasil penelitian yang dilakukan oleh Shyu dan kawan-kawan mengenai program perencanaan pulang yang berorientasi pada keluarga untuk pasien stroke, didapatkan bahwa keluarga-keluarga dari pasien stroke sering merasa tidak cukup siap untuk memenuhi kebutuhan fisik, kognitif, dan emosional pasien stroke. Keluarga pasien hanya mendapatkan sedikit informasi yang diperlukan untuk merawat pasien di rumah. Perawat kurang memberikan informasi mengenai hal-hal yang berhubungan dengan kebutuhan pasien sehari-hari dan bagaimana keluarga dapat mengatasi masalah yang muncul. Pemberian informasi dan discharge planning bermanfaat secara signifikan terhadap kemampuan keluarga dalam merawat pasien stroke di rumah utamanya pada bulan-bulan pertama setelah pulang dari rumah sakit (Shyu, 2008). Penelitian yang dilakukan oleh Rodger dan kawan-kawan, menemukan bahwa kurangnya informasi yang diberikan oleh perawat mengenai sifat, penyebab, dan konsekuensi dari stroke, serta ketersediaan layanan kesehatan menjadi kendala keluarga dalam merawat pasien stroke di rumah. Hal ini mungkin disebabkan karena 
informasi yang diberikan oleh perawat terlalu rumit, atau mungkin tidak relevan. Informasi yang diberikan cenderung pasif untuk memfasilitasi keluarga memperoleh ketrampilan dalam pemecahan masalah dan menyesuaikan diri dengan peran baru mereka. Padahal kondisi ketergantungan pasien dan gangguan kognitif, emosi, kecemasan yang dialami pasien dapat menimbulkan stress tersendiri bagi keluarga (Rodger, 2007).

Penanganan stroke secara umum dibagi menjadi dua tahap. Tahap pertama yaitu tahap akut, dimana sasaran pengobatan adalah untuk menyelamatkan neuron dan mencegah proses pathologik lainnya yang dapat mengancam fungsi otak. Pada tahap ini penatalaksanaan yang cepat dan tepat sangat diperlukan untuk memperbaiki dan mempertahankan fungsi otak optimal. Tahap kedua yaitu tahap pasca akut atau tahap pemulihan, dimana pasien membutuhkan penanganan yang komprehensif untuk meminimalkan kecacatan. Sasaran pengobatan dititikberatkan pada tindakan rehabilitasi, pencegahan komplikasi dan terjadinya stroke berulang (Harsono, 2000). Pasien stroke membutuhkan penanganan yang komprehensif, termasuk upaya pemulihan dan rehabilitasi jangka panjang, bahkan sepanjang sisa hidup pasien. Program rehabilitasi yang dijalankan harus sesuai dengan kemampuan dan derajat ketidakmampuan dari masing-masing individu itu sendiri. Keluarga pasien sendiri sangat berperan besar dalam tahap pemulihan ini, sehingga sejak awal perawatan diharapkan keluarga ikut terlibat pada penanganan pasien stroke. Pasien stroke akan memerlukan bantuan dalam melakukan aktivitas kehidupan sehari-hari, keluarga sebagai orang yang sangat dekat dengan pasien berperan besar dalam memberikan perawatan lanjutan dan memenuhi kebutuhan perawatan diri pasien (Smeltzer\&Bare, 2008).

Perawat mempunyai peranan yang sangat besar dalam memberikan dukungan dan asuhan keperawatan kepada pasien stroke dan keluarganya. Peran perawat dimulai dari tahap akut hingga tahap rehabilitasi serta pencegahan terjadinya komplikasi pada pasien stroke, sedangkan peran utama perawat terhadap keluarga pasien adalah meningkatkan koping keluarga melalui penyuluhan kesehatan. Peran perawat pada pasca rehabilitasi bukan hanya dalam hal pencegahan komplikasi dan mengurangi faktor resiko terjadinya stroke berulang, tetapi juga mengidentifikasi kebutuhan akan perencanaan pulang yang sesuai dengan kebutuhan perawatan pasien saat di rumah, memberikan informasi yang dibutuhkan, serta mendorong keluarga untuk lebih efektif dalam melaksanakan perannya pada pasien. Perencanaan pulang atau discharge planning merupakan proses yang dinamis agar tim kesehatan mendapatkan kesempatan yang cukup untuk menyiapkan pasien melakukan perawatan mandiri di rumah. Perencanaan pulang akan menghasilkan sebuah hubungan yang terintegrasi yaitu antara perawatan yang diterima pada waktu dirumah sakit dengan perawatan yang diberikan setelah pasien pulang. Perawatan di rumah sakit akan bermakna jika dilanjutkan dengan perawatan di rumah. Discharge planning yang belum berjalan optimal dapat mengakibatkan kegagalan dalam program perencanaan perawatan pasien di rumah yang akan 
berpengaruh terhadap tingkat ketergantungan pasien, dan tingkat keparahan pasien saat di rumah. Perencanaan pulang bertujuan untuk membantu pasien dan keluarga dapat memahami permasalahan dan upaya pencegahan yang harus ditempuh sehingga dapat mengurangi resiko kekambuhan (Nursalam, 2012). Peran keluarga sangat penting dalam tahaptahap perawatan kesehatan, mulai dari tahapan peningkatan kesehatan, pencegahan, pengobatan, sampai dengan rehabilitasi. Dukungan sosial dan psikologis sangat diperlukan oleh setiap individu di dalam setiap siklus kehidupan, dukungan sosial akan semakin dibutuhkan pada saat seseorang sedang menghadapi masalah atau sakit, disinilah peran anggota keluarga diperlukan untuk menjalani masa-masa sulit dengan cepat (Effendi, 2009).

Pemberian informasi yang adekuat melalui program discharge planning dapat meminimalkan kejadian yang tidak diinginkan, sehingga pendidikan kesehatan yang diberikan oleh perawat kepada pasien dan keluarga sangat dibutuhkan untuk merencanakan kesiapan pemulangan. Perawat bertanggung jawab untuk membuat rujukan yang sesuai dan memastikan bahwa semua informasi yang sesuai telah disediakan untuk orang-orang yang akan terlibat dalam perawatan pasien tersebut termasuk keluarganya. Pasien dan keluarganya harus mengetahui bagaimana cara memanajemen pemberian perawatan dirumah dan apa yang diharapkan didalam memperhatikan masalah fisik yang berkelanjutan karena kegagalan untuk mengerti pembatasan atau implikasi kesehatan (tidak siap menghadapi pemulangan) dapat menyebabkan pasien terjadi peningkatan komplikasi (Effendi, 2009). Kesiapan merupakan suatu sikap psikologis yang dimiliki seseorang sebelum melakukan sesuatu, dimana kesiapan ini dapat dipengaruhi oleh dirinya sendiri atau oleh pihak luar.

Hasil studi pendahuluan dengan melakukan wawancara terhadap 5 orang keluarga pasien stroke yang dirawat di RS. Islam Surabaya didapatkan bahwa semuanya mengatakan belum tahu cara merawat dengan benar keluarganya yang sakit terutama saat di rumah nanti. Pada saat ditanya tentang pengertian penyakit stroke dan apa penyebabnya, keluarga juga tidak dapat menjawab dengan benar. Mereka mengatakan ingin nantinya perawat memberi informasi secara jelas tentang penyakit stroke dan bagaimana cara merawatnya. Keluarga mengatakan mereka berharap keluarganya yang sakit segera sembuh dan dapat beraktifitas seperti sebelumnya. Hasil studi pendahuluan dengan melakukan wawancara kepada 6 perawat yang bekerja di sana didapatkan bahwa perencanaan pulang dilakukan pada saat pasien akan pulang yang berupa petunjuk pasien pulang. Pemberian perencanaan pulang meliputi informasi yang berkisar tentang waktu kontrol, cara minum obat, pemberian surat rujukan, surat sakit, dan perubahan gaya hidup yang harus dilakukan. Pemberian health education kepada pasien dan keluarga masih bersifat incidental yaitu jika ada pertanyaan dari pasien atau keluarganya saja dan belum dikemas dalam format pendidikan kesehatan yang sesuai dengan kondisi pasien. Perencanaan pulang yang efektif seharusnya 
dimulai pada saat pasien mendapatkan pelayanan kesehatan yang diikuti dengan kesinambungan perawatan baik dalam proses penyembuhan maupun dalam mempertahankan derajat kesehatannya sampai pasien merasa siap untuk kembali ke lingkungannya (Kozier, 2004). Berdasarkan uraian permasalahan di atas, peneliti tertarik untuk melakukan penelitian tentang "Efektifitas penerapan perencanaan pulang dengan metode terstruktur terhadap kesiapan keluarga dalam memberikan mobilisasi dini pada pasien stroke pasca akut di RS. Islam Surabaya.

\section{METODE PENELITIAN}

Penelitian ini merupakan jenis penelitian kuantitatif dengan menggunakan desain Quasy Experimental, Control Group Pre Test-Post Test Design.

Populasi penelitian adalah keseluruhan subyek penelitian yang akan diteliti. Populasi dalam penelitian ini adalah semua keluarga penderita CVA yang dirawat di RS. Islam Surabaya pada saat penelitian sebanyak 34 orang.

Kriteria inklusi dalam penelitian ini adalah:

1. Keluarga yang sama yang sering ditemui peneliti pada saat penelitian dilakukan, dan yang nantinya akan merawat pasien saat dirumah

2. Keluarga dari pasien CVA yang mengalami serangan pertama

3. Usia keluarga 18-60 tahun

4. Pendidikan keluarga minimal SMA
5. Bersedia diteliti dengan menandatangani informed consent Kriteria eksklusi dalam penelitian ini adalah:

1. Keluarga dengan latar belakang bidang kesehatan

2. Keluarga dari pasien stroke yang mengalami serangan ulang

3. Keluarga dari pasien stroke yang masih dalam kondisi kritis

Besar sampel sebanyak 30 orang yang kemudian dibagi menjadi 15 orang untuk kelompok eksperimen dan 15 orang untuk kelompok kontrol. Teknik sampling dalam penelitian ini menggunakan consecutive sampling.

Lokasi penelitian ini adalah ruang perawatan dewasa Rumah Sakit Islam Surabaya . Penelitian dilakukan pada bulan September - Desember 2016. Variabel independen adalah discharge planning dan untuk variabel dependen adalah kesiapan keluarga menggunakan yang diukur dengan lembar kuesioner dan Checklist.

Data yang telah terkumpul diolah dan disajikan dalam bentuk diagram distribusi frekuensi dan tabulasi silang, kemudian dianalisa menggunakan uji statistik. Uji statistik yang digunakan adalah Mann Withney dan dilakukan pengukuran odd ratio.

\section{HASIL PENELITIAN}

Tabel 5.2 Kesiapan keluarga dalam memberikan mobilisasi dini pada pasien CVA sebelum dan sesudah diberikan perencanaan pulang dengan metode terstruktur di Rumah Sakit Islam Surabaya bulan September- Desember 2016 


\begin{tabular}{lllllll}
\hline \multirow{2}{*}{ Kesiapan } & \multicolumn{3}{c}{ Perlakuan } & \multicolumn{3}{c}{ Kontrol } \\
\cline { 2 - 7 } & \multicolumn{2}{l}{ Siap (\%) } & $\begin{array}{l}\text { Tidak } \\
\text { Siap }(\%)\end{array}$ & $\mathrm{N}$ & Siap (\%) & $\begin{array}{l}\text { Tidak } \\
\text { Siap (\%) }\end{array}$ \\
\hline Sebelum & $0(0)$ & $15(100)$ & $15(100)$ & $0(0)$ & $15(100)$ & $15(100)$ \\
Sesudah & $8(53,33)$ & $7(46,66)$ & $15(100)$ & $2(13,33)$ & $13(86,66)$ & $15(100)$
\end{tabular}

\section{Sumber : Data primer, September- Desember 2016}

Berdasarkan tabel 5.2 dapat diketahui bahwa kesiapan kelompok perlakuan sebelum diberikan perencanaan pulang dengan metode terstruktur memiliki nilai persentase siap $0 \%$ dimana nilai persentase tersebut lebih kecil dari nilai persentase siap sesudah responden diberikan perencanaan pulang dengan metode terstruktur yaitu sebesar $53,33 \%$. Hal ini menunjukkan bahwa kesiapan responden sesudah diberikan perencanaan pulang dengan metode terstruktur lebih baik dibandingkan sebelum diberikan.

Kesiapan kelompok kontrol sebelum diberikan perencanaan pulang sesuai standar rumah sakit memiliki persentase siap $0 \%$ dimana nilai persentase tersebut lebih kecil dari nilai persentase siap sesudah responden diberikan perencanaan pulang yaitu sebesar 13,33\%. Hal ini menunjukkan bahwa kesiapan responden sesudah diberikan perencanaan pulang sesuai standar rumah sakit lebih baik dibandingkan sebelum diberikan.

Kesiapan kelompok perlakuan sesudah diberikan perencanaan pulang dengan metode terstruktur mempunyai nilai persentase $53,33 \%$ dimana nilai persentase tersebut lebih besar dari nilai persentase kesiapan kelompok kontrol sesudah diberikan perencanaan pulang sesuai standar rumah sakit yaitu sebesar 13,33\%. Hal ini menunjukkan bahwa kesiapan responden sesudah diberikan perencanaan pulang dengan metode terstruktur lebih baik dibandingkan dengan kesiapan responden sesudah diberikan perencanaan pulang sesuai prosedur rumah sakit.

Tabel 5.3 Pengaruh penerapan perencanaan pulang dengan metode terstruktur terhadap kesiapan keluarga dalam memberikan mobilisasi dini pada pasien CVA di Rumah Sakit Islam Surabaya bulan September-Desember 2016

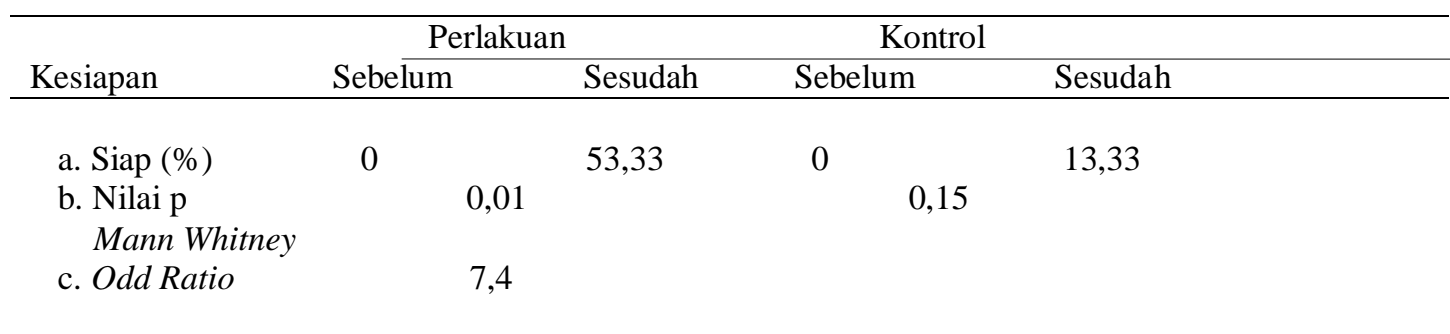

Sumber : Data primer, September-Desember 2016 
Berdasarkan tabel 5.3 dapat diketahui bahwa kesiapan kelompok perlakuan sesudah diberikan perencanaan pulang dengan metode terstruktur meningkat dari persentase $0 \%$ menjadi 53,33\%. Berdasarkan hasil uji statistik dengan Mann Whitney didapatkan nilai $\mathrm{p}=0,01$, dimana nilai $\mathrm{p}<0,05$ yang berarti terdapat pengaruh kesiapan keluarga sebelum dan sesudah diberikan perencanaan pulang dengan metode terstruktur.

Kesiapan kelompok kontrol sesudah diberikan perencanaan pulang sesuai prosedur rumah sakit juga meningkat dari persentase $0 \%$ menjadi 13,33\%. Hasil uji statistik dengan uji Mann Whitney didapatkan nilai $\mathrm{p}=$ 0,15 dimana nilai $p>0,05$ yang berarti tidak terdapat pengaruh kesiapan sebelum dan sesudah diberikan perencanaan pulang sesuai prosedur rumah sakit. Hasil perhitungan odd ratio menunjukkan bahwa pemberian perencanaan pulang dengan metode terstruktur mempunyai peluang 7,4 kali lebih besar untuk meningkatkan kesiapan keluarga dalam memberikan mobilisasi dini dibandingkan dengan diberi perencanaan pulang sesuai prosedur rumah sakit.

\section{PEMBAHASAN}

\section{A. Kesiapan Keluarga dalam Memberikan Mobilisasi Dini pada Pasien CVA Sebelum dan Sesudah Diberikan Perencanaan Pulang Dengan Metode Terstruktur}

Hasil interpretasi data yang dilakukan pada kelompok perlakuan berdasarkan tabel 4.2 dapat diketahui bahwa kesiapan kelompok perlakuan sebelum diberikan perencanaan pulang dengan metode terstruktur mempunyai nilai presentase siap $0 \%$ lebih kecil dibandingkan nilai persentase siap sesudah diberikan perencanaan pulang yaitu sebesar 53,33\%. Hal ini menunjukkan bahwa kesiapan keluarga untuk memberikan mobilisasi dini pada pasien CVA sesudah diberikan perencanaan pulang dengan metode terstruktur meningkat menjadi lebih baik dibandingkan sebelum diberikan. Hasil interpretasi data ini juga sama dengan hasil pada kelompok kontrol dimana kesiapan kelompok kontrol sebelum diberikan perencanaan pulang sesuai prosedur RS mempunyai nilai persentase siap 0\% lebih kecil dibandingkan nilai persentase siap sesudah diberikan perencanaan pulang yaitu 13,33. Hal ini menunjukkan bahwa kesiapan responden untuk merawat pasien stroke sesudah diberikan perencanaan pulang sesuai prosedur rumah sakit lebih baik dibandingkan sebelum diberikan.

Kesiapan keluarga mencakup pengetahuan dan ketrampilan keluarga dalam memberikan mobilisasi dini. Kesiapan pada responden kelompok intervensi sebelum diberikan perencanaan pulang menunjukkan tidak baik, hal ini disebabkan pengetahuan responden tentang penyakit stroke dan ketrampilan tentang cara memberikan mobilisasi dini tidak baik pula. Pengetahuan dan ketrampilan yang kurang baik dipengaruhi oleh belum adanya informasi kesehatan dari perawat atau petugas kesehatan lainnya yang sesuai dengan penyakit dan kebutuhan pasien. Pengetahuan dan ketrampilan keluarga menjadi meningkat setelah diberikan informasi kesehatan melalui kegiatan perencanaan pulang baik yang diberikan oleh peneliti maupun yang diberikan oleh perawat. Pengetahuan dan ketrampilan yang baik akan meningkatkan kesiapan 
keluarga dalam memberikan mobilisasi dini. Kesiapan merupakan suatu sikap psikologis yang dimiliki seseorang sebelum melakukan sesuatu, dimana kesiapan ini dapat dipengaruhi oleh dirinya sendiri atau oleh pihak luar. Kondisi kesiapan individu mencakup setidaknya tiga aspek yaitu kondisi fisik, mental dan emosional; kebutuhan-kebutuhan, motif dan tujuan; serta pengetahuan dan ketrampilan. Pengetahuan merupakan bagian penting dalam kesiapan. Pengetahuan atau ranah kognitif merupakan domain yang sangat penting dalam membentuk tindakan seseorang. Pengetahuan adalah hasil dari tahu dan ini terjadi setelah orang melakukan penginderaan terhadap suatu obyek tertentu melalui panca indera manusia, yaitu indera penglihatan, pendengaran, penciuman, rasa, dan raba. Ada beberapa faktor yang dapat mempengaruhi pengetahuan seseorang yaitu umur, pendidikan, pekerjaan, pengalaman, dan informasi (Notoadmodjo, 2012).

Salah satu faktor yang dapat mempengaruhi pengetahuan adalah umur seseorang. Tabel 5.1 menunjukkan bahwa pada kelompok perlakuan dan kelompok kontrol sebagian besar mempunyai umur 4160 tahun. Umur ini disebut juga usia dewasa madya atau dewasa penuh dimana kemampuan kognitif seseorang mencapai tingkatan intelektual puncak. Namun demikian, meskipun sebagian responden mempunyai usia dengan kemampuan kognitif yang optimal hasil penelitian menunjukkan bahwa pengetahuan mereka tentang penyakit CVA sebelum diberikan pendidikan kesehatan. Hal ini dapat disebabkan karena responden kurang terpapar informasi kesehatan khususnya tentang penyakit CVA dan cara perawatannya. Pemberian pendidikan kesehatan secara continue dan terencana yang diberikan pada usia yang optimal dapat meningkatkan pengetahuan dan ketrampilan seseorang secara optimal pula. Umur akan mempengaruhi daya tangkap dan pola pikir seseorang terhadap informasi yang diberikan. Daya tangkap ini akan berhubungan dengan maturitas dari fungsi tubuh baik indera maupun otak. Pada umur tersebut merupakan umur yang produktif dimana produktifitas kerja mampu dilakukan secara optimal dan keluhan kesehatan masih jarang diungkapkan. Maturasi fungsi tubuh, kesehatan, dan produktifitas yang optimal akan mempengaruhi masuknya informasi (Notoadmodjo, 2012).

Salah satu faktor yang dapat mempengaruhi pengetahuan adalah tingkat pendidikan seseorang. Tabel 5.1 menunjukkan bahwa pada kelompok perlakuan dan kelompok control sebagian besar mempunyai tingkat pendidikan SLTA, dan sebagian kecil mempunyai tingkat pendidikan perguruan tinggi. Semakin tinggi tingkat pendidikan responden akan semakin mudah dalam menerima segala bentuk informasi sehingga dapat meningkatkan pengetahuan khususnya tentang penyakit CVA dan cara perawatannya. Namun demikian, meskipun responden sudah mempunyai tingkat pendidikan SLTA dan perguruan tinggi hasil penelitian menunjukkan bahwa pengetahuan mereka tentang penyakit CVA dan cara perawatannya masih kurang baik sebelum diberikan pendidikan kesehatan. Hal ini dapat disebabkan karena responden kurang terpapar 
informasi kesehatan khususnya tentang penyakit CVA dan cara perawatannya. Pemberian pendidikan kesehatan secara continue dan terencana yang diberikan pada seseorang dengan tingkat pendidikan menengah keatas dapat meningkatkan pengetahuan dan ketrampilan seseorang secara optimal. Hal tersebut sesuai dengan pendapat Koentjoroningrat bahwa semakin tinggi pendidikan seseorang semakin mudah menerima informasi sehingga makin banyak pula pengetahuan yang dimiliki. Semakin tinggi pendidikan juga makin baik berkomunikasi dalam penyampaian serta penerimaan informasi (Notoadmodjo, 2012).

Salah satu faktor yang dapat mempengaruhi pengetahuan adalah pekerjaan seseorang. Tabel 5.1 menunjukkan bahwa pada kelompok perlakuan dan kelompok kontrol sebagian besar bekerja. Hasil penelitian menunjukkan bahwa pengetahuan responden tentang penyakit CVA dan cara perawatannya masih kurang baik sebelum diberikan pendidikan kesehatan. Sebenarnya seseorang yang bekerja secara tidak langsung akan mendapatkan pengalaman dan pengetahuan dari tempat kerjanya. Namun demikian, informasi kesehatan yang khusus tentang penyakit CVA dan cara perawatannya tidak bisa didapatkan dari tempat kerja pada umumnya. Informasi ini hanya bisa didapatkan dari tenaga kesehatan, internet, buku kesehatan, media cetak maupun media elektronik.

B. Pengaruh Penerapan Perencanaan Pulang Dengan Metode Terstruktur Terhadap Kesiapan Keluarga dalam Memberikan Mobilisasi Dini Pada Pasien Cerebro Vasculer Attack Berdasarkan tabel 5.3 diketahui bahwa terdapat peningkatan nilai persentase kesiapan baik pada kelompok perlakuan maupun pada kelompok kontrol. Peningkatan kesiapan pada kelompok perlakuan sesudah diberikan perencanaan pulang dengan metode terstruktur lebih baik dibandingkan kesiapan kelompok kontrol sesudah diberikan perencanaan pulang yang sesuai prosedur rumah sakit. Pemberian perencanaan pulang dengan metode terstruktur lebih efektif dalam meningkatkan kesiapan keluarga dalam memberikan mobilisasi dini pada pasien CVA.

Hasil analisis kesiapan dengan menggunakan uji statistik dengan Mann Whitney pada kelompok perlakuan didapatkan nilai $\mathrm{p}=0,01$ dimana nilai $\mathrm{p}<0,05$ yang berarti terdapat pengaruh kesiapan keluarga sebelum dan sesudah diberikan perencanaan pulang dengan metode terstruktur. Hasil ini menunjukkan bahwa kesiapan keluarga meningkat signifikan setelah diberikan perencanaan pulang dengan metode terstruktur.

Implementasi dalam perencanaan pulang dengan metode terstruktur berupa pemberian promosi kesehatan pada keluarga tentang penyakit CVA dan cara memberikan mobilisasi dini secara bertahap. Tujuannya adalah menyiapkan keluarga supaya memiliki pengetahuan dan ketrampilan dalam melakukan perawatan lanjutan saat dirumah terutama dalam melakukan mobilisasi dini . Promosi kesehatan yang diberikan pada keluarga dimulai ketika pasien mulai menjalani perawatan dan berakhir ketika pasien pulang yang dilakukan secara bertahap dengan perencanaan yang sistematis dan sesuai dengan kebutuhan pasien. Keluarga merupakan entry point dalam pemberian pelayanan kesehatan di masyarakat. Potensi dan 
keterlibatan keluarga menjadi semakin besar ketika salah satu anggota keluarganya memerlukan bantuan terus menerus karena masalah kesehatannnya bersifat kronik, misalnya seperti penderita pasca stroke. Proses keperawatan pada keluarga meliputi : pengkajian, diagnosis keperawatan, intervensi, implementasi, dan evaluasi. Tujuan dari asuhan keperawatan pada keluarga memandirikan keluarga dalam melakukan pemeliharaan kesehatan para anggotanya. Keluarga harus mampu memutuskan tindakan kesehatan yang tepat bagi keluarga, mampu merawat anggota keluarga yang mengalami gangguan kesehatan, mampu mempertahankan suasana di rumah yang sehat atau memodifikasi lingkungan untuk menjamin kesehatan anggota keluarga, mampu memanfaatkan fasilitas pelayanan kesehatan disekitarnya bagi keluarga. Masalah individu dalam keluarga diselesaikan melalui intervensi keluarga melalui keterlibatan aktif anggota keluarga lain (Nursalam, 2012).

Hasil analisis kesiapan pada kelompok kontrol dengan menggunakan uji Mann Whitney didapatkan nilai $\mathrm{p}=0,15$ dimana nilai $\mathrm{p}>0,05$ yang berarti tidak terdapat pengaruh kesiapan sebelum dan sesudah diberikan perencanaan pulang sesuai prosedur rumah sakit. Hasil ini menunjukkan bahwa kesiapan keluarga sebenarnya tetap mengalami peningkatan setelah diberikan perencanaan pulang sesuai prosedur rumah sakit tetapi peningkatannya tidak begitu signifikan.

Pemberian perencanaan pulang sesuai prosedur rumah sakit dilakukan hanya pada saat pasien akan pulang yang berupa petunjuk pasien pulang. Pemberian perencanaan pulang pada keluarga dan pasien meliputi informasi yang berkisar tentang waktu kontrol, cara minum obat, pemberian surat rujukan, surat sakit, dan perubahan gaya hidup yang harus dilakukan. Informasi ini belum dikemas dalam format pendidikan kesehatan yang sesuai dengan kondisi pasien. Keluarga tidak diberikan promosi kesehatan yang memadai tentang penyakit CVA dan cara perawatan lanjutan saat di rumah nanti termasuk didalamnya cara melakukan mobilisasi dini secara bertahap. Perencanaan pulang yang efektif seharusnya dimulai pada saat pasien mendapatkan pelayanan kesehatan yang diikuti dengan kesinambungan perawatan baik dalam proses penyembuhan maupun dalam mempertahankan derajat kesehatannya sampai pasien merasa siap untuk kembali ke lingkungannya ( Nursalam, 2012).

Peningkatan secara signifikan kesiapan keluarga setelah diberikan perencanaan pulang dengan metode terstruktur diperkuat dengan hasil perhitungan odd ratio yang menunjukkan bahwa pemberian perencanaan pulang dengan metode terstruktur mempunyai peluang 7,4 kali lebih besar untuk meningkatkan kesiapan keluarga dibandingkan dengan diberi perencanaan pulang sesuai prosedur rumah sakit.

\section{KESIMPULAN DAN SARAN}

A. Kesimpulan

Hasil penelitian yang dilaksanakan di RS. Islam Surabaya didapatkan kesimpulan sebagai berikut:

1. Kesiapan keluarga dalam memberikan mobilisasi dini pada pasien cerebro 
vaskuler attack meningkat sesudah diberikan perencanaan pulang dengan metode terstruktur di RS. Islam Surabaya.

3. Penerapan perencanaan pulang dengan metode terstruktur meningkatkan kesiapan keluarga dalam dini pada pasien cerebro vaskuler attack di RS. Islam Surabaya.

B. Saran

1. Pelayanan Keperawatan

a. Diharapkan perawat dapat menggunakan hasil penelitian ini sebagai pedoman dalam penerapan perencanaan pulang pada pasien cerebro vascular attack sehingga kemampuan keluarga dalam memberikan perawatan lanjutan dirumah meningkat.

b. Diharapkan pasien cerebro vascular attack dan keluarga bersedia mengikuti panduan yang telah diberikan dalam penelitian ini sehingga terjadi perubahan perilaku (dengan peningkatan kognitif, afektif serta psikomotor), kesiapan keluarga untuk memberikan perawatan lanjutan meningkat, motivasi pasien untuk sembuh lebih baik, dan kekambuhan penyakit dapat dicegah.

2. Profesi Keperawatan

Diharapkan hasil penelitian ini dapat digunakan sebagai acuan oleh organisasi profesi keperawatan untuk mengembangkan ilmu keperawatan bidang manajemen khususnya perencanaan pulang sebagai salah satu tindakan keperawatan mandiri.

3. Penelitian Keperawatan

a. Diharapkan pada peneliti selanjutnya untuk melakukan perluasan populasi yaitu pada penyakit kronis lainnya.

b. Diharapkan pada peneliti selanjutnya untuk melakukan penelitian dengan teknik perencanaan pulang yang lain

c. Diharapkan perencanaan pulang diikuti sampai di rumah (post discharge planning) untuk menilai sampai terjadinya perubahan perilaku.

\section{DAFTAR PUSTAKA}

Effendi, F \& Mahfudi. Keperawatan Kesehatan Komunitas Cetakan Pertama. Jakarta:

Salemba Medika. 2009

Febrie Suryantika. Gambaran Fungsi Kognitif Pada Pasien Stroke Post Opname di

Poliklinik. http:// www. Academia.edu. 2013. diperoleh tanggal 12 Desember 2014

Friedman, M.M, Bowden, V.R, \& Jones, E.G. Buku Ajar Keperawatan Keluarga: Riset, Teori, dan Praktik, Alih Bahasa Akhiri Yani S. Hamid dkk. Ed 5. Jakarta: EGC. 2010

Kozier, B. Fundamental Of Nursing Concept Process and Practice. $1^{\text {st }}$ Volume 6 th Edition. New Jersey. Pearson/Prentice Hall. 2004

Lanny, Lingga. All About Stroke Hidup Sebelum dan Pasca Stroke. Jakarta: Pt Elex

Media Komputindo. 2013

Notoadmodjo. Promosi Kesehatan dan Perilaku Kesehatan. Jakarta: Rineka Cipta. 2012

Nursalam. Keperawatan Manajemen Aplikasi Dalam Praktek Keperawatan Profesional. Edisi 3. Jakarta: Salemba Medika. 2012

Nursalam. Konsep dan Penerapan Metodologi Penelitian Pedoman Skripsi, Tesis dan Instrumen Penelitian Keperawatan Edisi 2. Jakarta : Salemba Medika. 2003 
Perry AG \& Potter PA. Clinical Nursing Skill \& Technique. $6^{\text {th }}$ edition. Missouri: Mosby Inc. 2006

Price S \& Wilson L. Patofisiologis. Konsep Klinis Proses proses Penyakit. Edisi 6. Jakarta: EGC. 2006

Rodgers. Who Care?- Caring For The Carers of Stroke patient. http:/www.abdn.ac.uk/healthpsy ychology/publications/2007_D\& R_Rodgers Care. Diperoleh tanggal 12 Desember 2014
Smeltzer\&Bare. Brunner \& Suddart: Textbook of Medikal Surgical Nursing. Philadelphia: Lippincott Williams \&Walkins. 2008

Shyu LYI, Chen MC, Chen CS, Wang SP, \& Shao JH. A Family Caregiver Oriented Discharge Planning Program For Older Stroke Patients and Their Family Caregiver. Journal OF Clinical Nursing. 17: 2497-2508. 2008 